\title{
Adult Langerhans cell histiocytosis: a rare cause of colon polyp
}

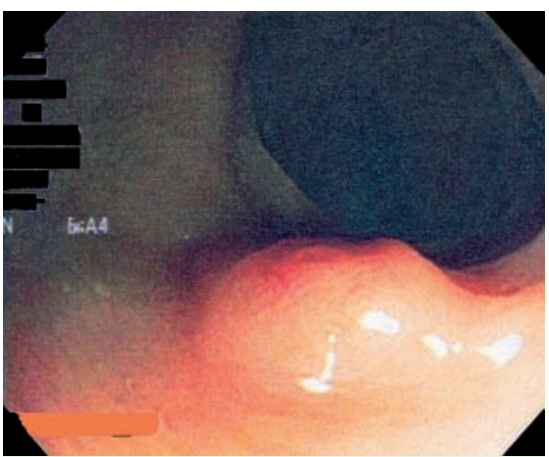

Fig. 1 Endoscopic view of the Langerhans cell histiocytosis polyp.

A 65-year-old man with no prior medical problems underwent a screening colonoscopy. He was an ex-smoker with a 100 pack-year cigarette smoking history. A 6-mm sessile, benign-appearing polyp was removed from the descending colon using snare diathermy ( $\bullet$ Fig. 1).

No other lesions were noted on colonoscopy. Histology showed a nodular proliferation of histiocytic cells within the submucosa, accompanied by a moderate number of eosinophils and lymphoid cells ( $\bullet$ Fig. 2 and 3 ).

Immunoperoxidase studies showed that the histiocytic cells were reactive to S100, CD68, and CD1a antigens ( $\bullet$ Fig. 4). Based on these results, a diagnosis of Langerhans cell histiocytosis was made. Chest and skull radiographs, bone scan, and an abdominal ultrasound were unremarkable. High-resolution computed tomography of the chest, and bone marrow aspiration and biopsy were normal. As the patient was clinically asymptomatic and the entire work-up did not reveal any other organ involvement, no therapy was initiated; 1 year later, he remains asymptomatic on regular follow-up.

Langerhans cell histiocytosis is rare in adults [1], and gastrointestinal tract involvement is even rarer [2-4]. With the increasing number of colonoscopies being performed, gastroenterologists should be aware of this rare cause of colon polyps to ensure proper follow-up and further testing to rule out systemic disease.

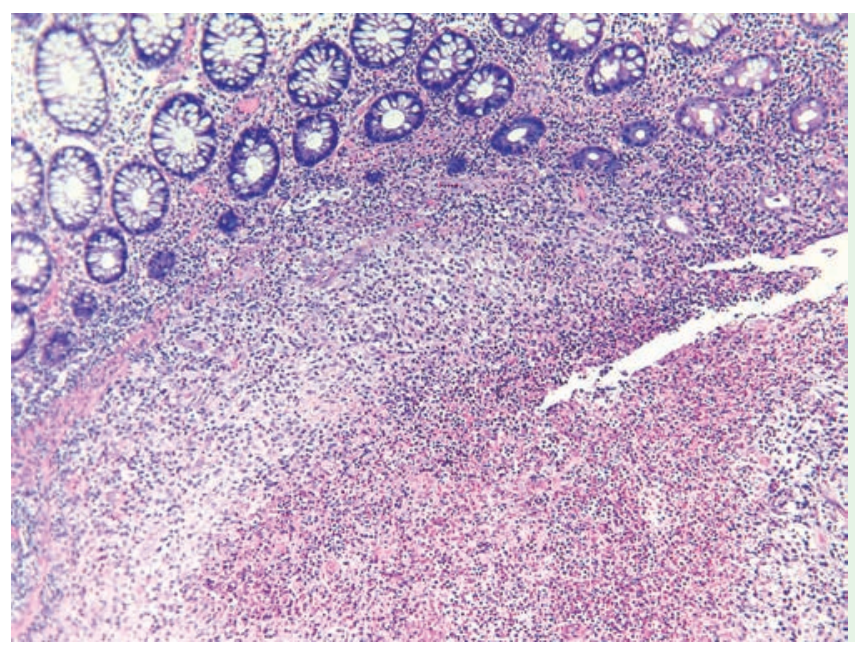

Fig. 2 Medium magnification image of benign colonic mucosa overlying core of polyp, exhibiting pale histiocytic cells and eosinophils (hematoxylinphloxine-safranin stain, $\times 100$ ).

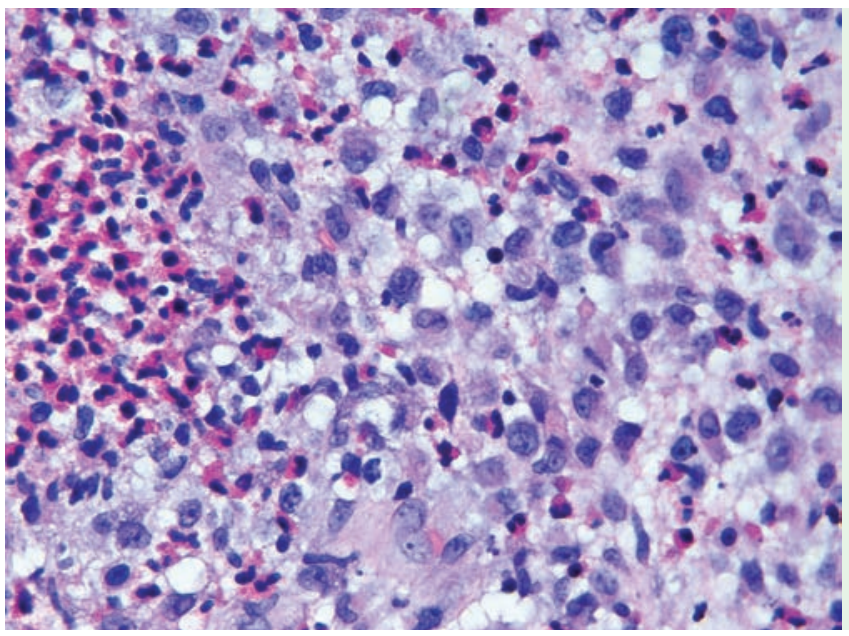

Fig. 3 High-magnification image of colonic polyp, exhibiting histiocytic cells with pale cytoplasm and admixed eosinophils (hematoxylin-phloxinesafranin stain, $\times 400$ ).

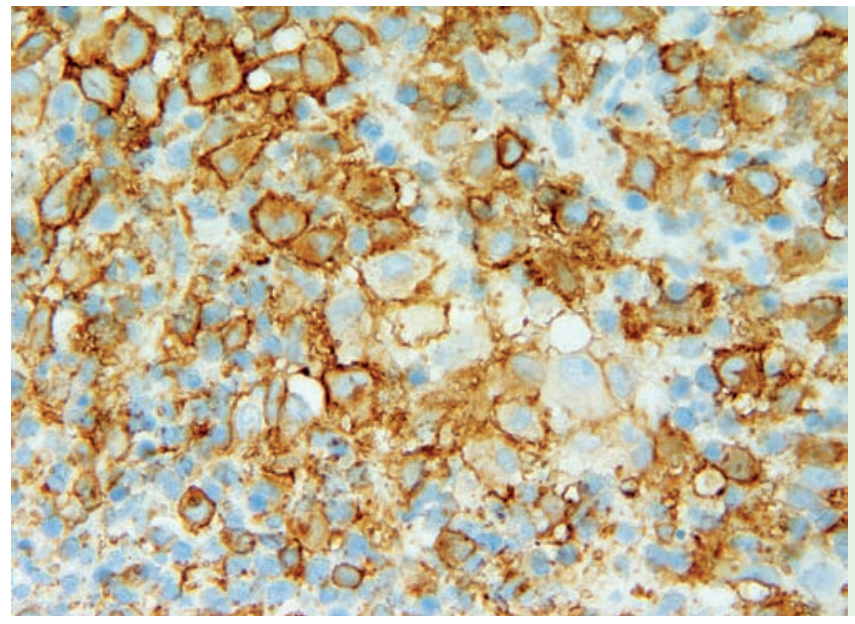

Fig. 4 Immunoperoxidase reaction of lesional cells with antiCD1a antibodies, characteristic of Langerhans cells (anti-CD1a with hematoxylin counterstain, $\times 400$ ). 
R. Kibria ${ }^{1}$, P. M. Gibbs ${ }^{2}$, D. M. Novick ${ }^{1}$

1 Gastroenterology, Wright State University School of Medicine, Dayton, Ohio, USA

2 Anatomical and Clinical Pathology, Wright State University School of Medicine, Dayton, Ohio, USA

\section{References}

1 Stockschlaeder M, Sucker C. Adult Langerhans cell histiocytosis. Eur J Haematol 2006; 76: $363-368$

2 Sharma S, Gupta M. A colonic polyp due to Langerhans cell histiocytosis: a lesion not to be confused with metastatic malignant melanoma. Histopathology 2006; 49: 438 439

3 Nihei K, Terashima K, Aoyama Ket al. Benign histiocytosis X of stomach. Previously undescribed lesion. Acta Pathol Jpn 1983; 33 . 577-588

4 Iwafuchi M, Watanabe H, Shiratsuka M. Primary benign histiocytosis $\mathrm{X}$ of the stomach. A report of a case showing spontaneous remission after $51 / 2$ years. Am J Surg Pathol 1990; 14: 489-496
Bibliography

DOI 10.1055/s-0029-1214689

Endoscopy 2009; 41: E160 -E161

(c) Georg Thieme Verlag KG Stuttgart · New York . ISSN 0013-726X

\section{Corresponding author}

\section{R. Kibria, MD}

Gastroenterology

Wright State University School of Medicine 4100 W. Third Street

Dayton

Ohio 45428

USA

Fax: +1-937-268-6511

rekibria@gmail.com 